\title{
„Trudno znaleźć coś lepszego” \\ O polsko-izraelskich splotach pamięci o Zagładzie z Shoshaną Ronen rozmawiają Jagoda Budzik i Bartłomiej Krupa
}

Jagoda Budzik: Jako że nasza rozmowa ma dotyczyć sposobów funkcjonowania odniesień do Zagłady nie tylko w izraelskiej literaturze, lecz także w dyskursie publicznym, zarówno w Polsce, jak i w Izraelu, trudno nie zacząć jej od kwestii najbardziej aktualnej, czyli debaty toczącej się wokół ustawy o Instytucie Pamięci Narodowej. Wydaje się, że reakcje, jakie wywołała ona w Polsce i w Izraelu, wiele mówią o miejscu Zagłady w zbiorowych narracjach obu krajów - na pozór przestała ona (choć można powiedzieć, że w Polsce nigdy tak naprawdę nie zaczęła) być istotnym tematem, tymczasem okazało się, że wciąż tkwi w ludziach bardzo głęboko. Symptomatyczny jest już sam fakt, że w Izraelu ten wątek podjęli natychmiast nie tylko politycy $\mathrm{z}$ obydwu stron sceny politycznej, lecz także prasa - zarówno „Haaretz”, jak i gazety prawicowe, na przykład „Israel Hajom", co zresztą nie dziwi. Interesujące jest to, że w ten dyskurs włączyli się również ci, którzy dotąd deklarowali, że mają już dosyć ciągłego powracania do Zagłady, i próbowali kierować uwagę na inne kwestie - na okupację, rasizm, grupy podlegające wykluczeniom itd.

Shoshana Ronen: Dla mnie to, że niektórzy mają dość ciągłego odwoływania się do Zagłady, nie jest żadnym zaskoczeniem, bo w izraelskiej codzienności Holokaust jest ciągle obecny, zwłaszcza w polityce. Widać to na przykład w wypowiedziach premiera Benjamina Netanjahu, który mówiąc o zagrożeniu ze strony Iranu, posługuje się metaforą "nowego Hitlera”. To zresztą figura na

\footnotetext{
${ }^{1}$ „Haaretz” - jeden z najpopularniejszych izraelskich dzienników, światopoglądowo utożsamiany $\mathrm{z}$ opcją liberalną.
} 
tyle nośna, że zawsze znajdzie się jakiś „nowy Hitler”, z którym trzeba będzie walczyć, co oczywiście jest czystą demagogią, wciąż jednak wykorzystywaną i tego właśnie część izraelskiego społeczeństwa ma już dosyć. A jednocześnie pamięć o Zagładzie jest tak mocno wpisana w zbiorową tożsamość, że tego rodzaju spory angażują bardzo szerokie kręgi i budzą emocje. Wydaje mi się jednak, że istotniejsza jest tutaj inna kwestia. Próbuje się nas przekonać, że ustawa, o której mówimy, ma na celu karanie osób posługujących się określeniem „polskie obozy zagłady", ale to nieprawda - nie ma w niej nic na temat tego sformułowania. Moim zdaniem chodzi raczej o zniechęcenie nowego pokolenia badaczy, o to, żeby nie zajmowali się tematami niewygodnymi z punktu widzenia tzw. polskiej polityki historycznej. W Izraelu nikt nie mówi „polskie obozy śmierci”, używa się sformułowania machanot haszmada (obozy śmierci) albo machanot ha-haszmada ha-nacim (nazistowskie obozy śmierci). Sformułowanie Polish death camps pojawia się czasem $\mathrm{w}$ wypowiedziach angielskich, ale nie po hebrajsku.

Bartłomiej Krupa: To jest to, o czym wielokrotnie mówił Piotr Paziński pewne rzeczy docierają do nas za pośrednictwem języka angielskiego. Prezydent Barack Obama użył przecież takiego określenia, więc wydaje się, że trafiło ono do obydwu stron przez wspólnego pośrednika.

Sh.R.: O ciekawej reakcji, czy właściwie geście protestu przeciw polskiej ustawie, jaki pojawił się w izraelskim Internecie, powiedzieli mi studenci. Nie mam konta na Facebooku, ale podobno Izraelczycy z rozmysłem masowo używają teraz w postach określenia „polskie obozy śmierci”, co dotąd było niespotykane.

J.B.: Po części pewnie dlatego, że jeśli ktoś mówił: „jadę do Polski”, to do pewnego momentu było oczywiste, że będzie odwiedzał Auschwitz i inne miejsca pamięci. Można w pewnym uproszczeniu powiedzieć, że przez długi czas Polska była w zasadzie postrzegana przez izraelskich Żydów jako jeden wielki obóz zagłady, jakkolwiek ostatnio zaczęło to ulegać zmianie. Zdaje się, że debata, która toczy się teraz, ma istotny wpływ na obraz Polski w Izraelu, choć tak naprawdę jej odbicie w izraelskiej narracji mogłoby też dowodzić, że obraz ukształtowany po wojnie dominuje do dziś.

Sh.R.: Od jakiegoś czasu zwrot „jadę do Polski” oznacza także po prostu: „jadę na zakupy". Pod tym względem naprawdę dużo się zmieniło. Widzę to również po reakcjach, których sama doświadczam. Żyję w Polsce już 25 lat i pamiętam, że na początku, kiedy mówiłam, że tutaj mieszkam, reakcje były bardzo różne, na przykład: co tam się robi? Musiałam tłumaczyć wiele rzeczy, wyjaśniać też, że Polacy nie są antysemitami. Choć, prawdę mówiąc, kiedy czytam teraz różne doniesienia $\mathrm{w}$ gazetach lub w Internecie albo słucham wypowiedzi polityków, to dochodzę do wniosku, że może w niektórych przypadkach nie miałam racji... 
Ale w ostatnich latach, mniej więcej od dekady, a może trochę dłużej, reakcje Izraelczyków były całkiem inne: „o jak fajnie, również byłam w Polsce, widziałam jakieś ciekawe miejsce”. To oznaczałoby, że nastąpiła zmiana, i w kontekście tego, co dzieje się teraz, jeżeli Polska i Izrael dojdą do jakiegoś kompromisu, to Izraelczycy zapomną o sprawie, bo naprawdę mają już dość Holokaustu.

B.K.: Mnie też się tak wydaje. Kiedy mieszkałem pół roku w Jerozolimie i chodziłem na uniwersytet, jednego razu strażnik, gdy dowiedział się, że jestem z Polski, sięgnął po notesik, gdzie wypisywał polskie słówka. Był zainteresowany mną i Polską. Moi przyjaciele rzeczywiście przylatują na zakupy do Polski, bo twierdzą, że w Warszawie są wspaniałe sklepy. A przede wszystkim tanie.

J.B.: Przypomina mi się skecz Sochnej mesilot ${ }^{2}$ grupy Ha-Chamiszija ha-Kamerit, niezwykle popularnego kiedyś kabaretu, pokazywanego w telewizji. Pracownica biura podróży przedstawiała w nim wspaniałą ofertę: „Polska - pakiet podstawowy: dwanaście obozów w siedem dni i jeden dzień wolny na zakupy". Powstał jeszcze w latach 90., a teraz wydaje mi się, że te proporcje się zmieniają...

Sh.R.: ...że jeden dzień na obozy, bo tak trzeba, i cztery dni na zakupy. Półżartem powiem tylko, co słyszałam - podobno latają z dwiema walizkami i jedną zabierają pustą. W porównaniu z Izraelem wszędzie jest tanio, może poza Norwegią.

B.K.: Rozmowa zeszła nam na nieco przyziemne tematy, ale wydaje mi się, że dobrze pokazuje dość dziwny mariaż, z jakim mamy do czynienia, jeśli chodzi o obraz Polski w Izraelu. Z jednej strony pojawiają się treści pochodzące z popkultury, z drugiej zaś - to wątek, który pamiętam z Twojego wykładu w Pracowni Pytań Granicznych UAM - powraca szczególny rodzaj traumy naznaczającej izraelskie społeczeństwo. Wydaje mi się, że reakcje na to, co dzieje się w Polsce, stanowią potwierdzenie działania różnego rodzaju resentymentów.

Sh.R.: Dystans czasowy dzielący izraelskie społeczeństwo od Zagłady wciąż nie jest wystarczająco duży, by je wyeliminować. Resentymenty przenoszą się przez rodzinne opowieści (a często też przez milczenie na temat tego, co się zdarzyło) i różnego rodzaju uwarunkowania - rodziny ocalałych, którzy w Zagładzie stracili bliskich, nie są tak liczne jak rodziny innych. Przekonanie o bez przerwy czyhającym na Żydów niebezpieczeństwie jest częścią oficjalnego dyskursu. Nie chodzi o to, że społeczeństwo świadomie wybiera taki obraz, to raczej stopień

${ }^{2}$ Tytuł ten opiera się na grze słów: sochnej nesi'ot oznacza po hebrajsku 'biuro podróży', podobnie brzmiące mesilot oznacza natomiast 'tory kolejowe', co budzi oczywiste skojarzenia z Zagładą. 
zakorzenienia pamięci o Szoa na różnych poziomach życia codziennego nie pozostawia wyboru. To naprawdę nie jest tak, że ludzie chcą tym żyć na co dzień.

B.K.: To wynika $z$ lęku działającego na głębokim poziomie. Podobnie jest w Polsce, jeśli spojrzymy na dyskurs podtrzymujący poczucie zagrożenia ze strony sąsiadujących z nami imperiów, Niemiec i Rosji, które gotowe są zaatakować nas $\mathrm{z}$ obu stron. Marcin Król nazwał to kiedyś syndromem Zbaraża ${ }^{3}$, czyli twierdzy, która w pewnym sensie broniła się podobnie jak Masada...

Sh.R.: Ale to też jest wyimaginowane...

J.B.: Problem polega na tym, że i Polacy, i Izraelczycy rywalizują o miano największej ofiary tego samego wydarzenia...

Sh.R.: Był taki skecz, który napisał Etgar Keret, zresztą także dla Ha-Chamiszija ha-Kamerit, zatytułowany Olimpiada. Podczas jednej z konkurencji lekkoatletycznych do niemieckiego sędziego podchodzą działacze izraelskiej reprezentacji i proszą o taryfę ulgową. Mówią, że ich zawodnik (oczywiście z numerem sześć na koszulce ${ }^{4}$ ) jest niski i wygląda na słabego, więc powinno mu się pozwolić przesunąć nieco bliżej mety i wystartować chwilę wcześniej. Sugerują Niemcowi, że jest im coś winien. Chęć bycia największą ofiarą jest zarazem śmieszna i żałosna - i to po obu stronach. Nie wiem, czy jestem obiektywna, pewnie nie, ale istnieje jednak jakaś różnica. Ewa Kurek mówiła, że Żydzi zdradzali Polaków i uciekali do getta (śmiech). Wszystko można powiedzieć, ale jednak los Żydów i Polaków nie był identyczny.

B.K.: Miałem na myśli podobieństwo pewnych mechanizmów psychicznych, choć ich poziom historyczny rzeczywiście jest różny.

J.B.: Nie wiem, jakie odczucia towarzyszyły Ci, gdy pisałaś książkę Polin. A Land of Forests and Rivers ${ }^{5}$, w której dużo miejsca poświęcasz stereotypowemu przedstawianiu Polski przez izraelskich autorów i niekiedy być może nieco nadmiernemu posługiwaniu się kliszą Polski jako żydowskiego cmentarza. Osobiście często uświadamiam sobie różnicę perspektyw - w Izraelu pamięć o Zagładzie

${ }^{3}$ Zob. M. KRóL: Podróż romantyczna. Paryż 1986, s. 25: „Dzieje Zbaraża, to zatem historia zwycięstwa wciąż się powtarzającego, zwycięstwa mezzo termino nad silnym tonem, zwycięstwa strategii defensywnej nad pozycjami ofensywy, zwycięstwa solidaryzmu nad pluralizmem, zwycięstwa moralistyki nad metafizyką z jednej i polityką z drugiej strony”. Dalej Król wyjaśnia: „Kiedy zatem mówię o Nieustającym Zbarażu, myślę o obozie warownym, którego historia rozpoczyna się w końcu XVIII wieku i trwa po dziś dzień" (s. 26).

${ }^{4}$ To aluzja do $6 \mathrm{mln}$ Żydów zamordowanych podczas Szoa, liczby silnie akcentowanej $\mathrm{w}$ izraelskim dyskursie zagładowym.

${ }^{5}$ Sh. Ronen: Polin. A Land of Forests and Rivers. Warszawa 2007. 
przedostaje się do wielu sfer życia, również tych zupełnie z nią niezwiązanych, w Polsce - na odwrót. Wątek Zagłady podlega w debacie publicznej cenzurze i licznym ograniczeniom. Obydwa te mechanizmy poddawane są uzasadnionej krytyce, choć - jak się zdaje - z różnych stron.

Sh.R.: To faktycznie paradoks, choć te mechanizmy są od siebie niezależne. Stanowią dwa odrębne przykłady tego, jak różny może być status Szoa zależnie od prowadzonej polityki historycznej. Choć teraz przecież dużo mówi się w Polsce o Zagładzie...

B.K.: Tak, ale ostatnio politycy chcą przede wszystkim zwracać uwagę na bohaterstwo Polaków - powstało na przykład Muzeum Polaków Ratujących Żydów podczas II wojny światowej im. Rodziny Ulmów. W tym kontekście mówi się raczej o Sprawiedliwych niż o ofiarach.

Sh.R.: Byłam w muzeum w Markowej i uderzyło mnie jednostronne przedstawienie tej historii. Nikt nie słucha badaczy, którzy piszą, kto donosił, na przykład na Ulmów...

B.K.: Tego rodzaju badania wywołują kontrowersje - Jan Grabowski i Dariusz Libionka opublikowali artykuły na ten temat nie tylko w specjalistycznych pismach, lecz także w prasie codziennej ${ }^{6}$, ale na przykład Mateusz Szpytma przekonywał, że w przypadku Markowej współudział Polaków nie jest udowodniony... ${ }^{7}$

J.B.: Ostatnio słyszałam, że w związku z tym, że Wiktoria Ulma była w ciąży, kiedy została zabita, muzeum w Markowej stało się obiektem zainteresowania ruchów antyaborcyjnych ${ }^{8}$. W Polsce bardzo często wiąże się dyskurs zagładowy z tematami wygodnymi dla prawicy, padają na przykład hasła o holokauście zarodków, o samej Zagładzie w Polsce raczej się nie rozmawia. Inaczej wyglada to w Izraelu, gdzie jest ona wszechobecna, w zasadzie jest w powietrzu, jak religia, dlatego chciałabym chwilę skupić się na Twojej książce, którą już wspomniałam. Bardzo przekrojowo analizujesz w niej podejmującą temat Zagłady literaturę hebrajską, która zaczęła powstawać wraz z pierwszymi doniesieniami o tym, co dzieje się w Europie, i w związku z tym wykorzystuje też obrazy Polski. Układ książki jest jednak problemowy, a nie chronologiczny, dlatego warto byłoby porozmawiać o tym, kiedy temat Zagłady zaczął się pojawiać w literaturze izraelskiej.

${ }^{6}$ Zob. np. J. Grabowski, D. Libionka: Wsadzili ich na wozy, powieźli jak bydło. „Gazeta Wyborcza” z 10 grudnia 2016 r., s. 12; Ciż: Pomagali i zabijali. „Gazeta Wyborcza” z 7 stycznia 2017 r., s. 25.

7 M. Szpytma: Czyje te bezdroża? „Gazeta Wyborcza” z 7 stycznia 2017 r., s. 25.

${ }^{8}$ Można by to połączyć z publikacjami D. Libionki i J. Grabowskiego o Muzeum w czasopiśmie „Zagłada Żydów. Studia i Materiały” (2017, nr 13). 
Sh.R.: Badacze zasadniczo zgadzają się co do tego, że na szerszą skalę i również poza syjonistyczną narracją temat ten zaczął pojawiać się po procesie Adolfa Eichmanna, który odbył się w 1961 roku. Oczywiście byli pisarze, którzy podejmowali ten problem już krótko po wojnie czy nawet w jej trakcie, na przykład Chajim Guri ${ }^{9}$ albo Aharon Megged ${ }^{10}$, o których akurat nie pisałam. Ta kwestia faktycznie była obecna zawsze, choć nie istniała - poza oficjalnym dyskursem jedna ustalona formuła pisania o Zagładzie. Należy tu wspomnieć o Aharonie Appelfeldzie, który o Szoa zaczął pisać w latach 50. XX wieku i robił to konsekwentnie aż do swojej niedawnej śmierci ${ }^{11}$.

Nie przypominam sobie natomiast, żeby Zagłada była silnie obecna w dyskursie publicznym w czasach, gdy sama chodziłam do szkoły. Kiedy byłam dzieckiem, nie uczyłam się o Szoa na lekcjach historii ani żadnych innych, nie organizowano jeszcze wtedy wycieczek szkolnych do Polski - zaczęły się one później, pod koniec lat 80. Kiedy w 1977 roku do władzy doszła prawicowa partia Likud, ten stan utrzymywał się jeszcze tylko przez trzy lub cztery lata. Nowy premier, Menachem Begin, bardzo często poruszał natomiast temat Holokaustu, włączono go też do szkolnych programów nauczania. Pamiętam jednak, że w mojej szkole mieliśmy jeden dzień w roku, Jom ha-Szoa, kiedy trzeba było ubrać się na galowo, odbywała się akademia, czytane były wiersze Hanny Szenes, śpiewało się Hatikwę, było raczej patetycznie, ale to wszystko. O Zagładzie wiedziałam trochę $\mathrm{z}$ domu, bo moja mama jest dzieckiem Holokaustu, ale nie mogę powiedzieć, że to był temat obecny w społeczeństwie w latach 80 . Ta obecna głośna fala pisania o Szoa dopiero się wtedy zaczynała, do głosu zaczęło dochodzić drugie pokolenie. Czy to konsekwencja obecności Zagłady w szkole, w dyskursie politycznym i społecznym? Czy literatura jest jednym z tych elementów?

Ciekawe, czy gdyby Dawid Grossman, który pod względem biograficznym nie należy do drugiego pokolenia, nie napisał Patrz pod: Miłośćc ${ }^{12}$, nie stałoby się inaczej? Czy ktoś wiedziałby o istnieniu Nawy Semel ${ }^{13}$ albo Savyon Liebrecht ${ }^{14}$ ? Czy to nie jest tak, że to właśnie Grossman otworzył im drzwi? Jego książka na początku wzbudziła wiele kontrowersji, dostała mnóstwo negatywnych recenzji.

9 Chajim Guri (1923-2018) - izraelski pisarz, poeta, dziennikarz i twórca filmów. Laureat Nagrody Izraela w dziedzinie poezji w $1988 \mathrm{r}$.

${ }_{10}$ Aharon Megged (1920-2016) - izraelski pisarz, laureat Nagrody Izraela w dziedzinie literatury w $2003 \mathrm{r}$.

${ }^{11}$ Aharon Appelfeld (ur. w 1932 r. w Czerniowcach) zmarł 4 stycznia 2018 r. w Petach Tikwie. Spośród kilkudziesięciu napisanych przez niego powieści po polsku ukazały się dwie: Badenheim 1939 i Droga żelazna.

${ }^{12}$ D. Grossman: Patrz pod: Miłość. Przeł. M. Sommer. Warszawa 2004.

${ }^{13}$ Nawa Semel (1954-2017) - pisarka izraelska należąca do drugiego pokolenia po Zagładzie, autorka powieści i wierszy.

${ }^{14}$ Savyon Liebrecht (ur. w 1948 r.) - izraelska pisarka i autorka dramatów, z których kilka przetłumaczono na język polski - ukazały się w tomie: S. Liebrecht: Rzecz o banalności... i inne sztuki. Przeł. M. Sobelman. Warszawa 2012. 
Pisano, że to ogromna porażka. Nawet tak ważny krytyk jak Amnon Nawot dołączył do chóru niezadowolonych. Pisał, że wspomniana powieść jest profanacją, zastanawiał się, jak Grossman w ogóle śmiał poruszyć ten temat. Krytyk nie mógł zrozumieć, jak można przyjąć punkt widzenia esesmana i przedstawić go jako człowieka ${ }^{15}$.

J.B.: W tym kontekście ważne jest chyba to, o czym wspominała Iris Milner, że nawet jeśli Zagłada pojawiała się w literaturze hebrajskiej, to albo z perspektywy powojennej, albo w pewnym sensie „krążono” wokół niej. Pisarze bardzo rzadko „wchodzili” ze swoją perspektywą do obozu i opisywali same wydarzenia.

Sh.R.: Tak, to było duże tabu. Nawet Aharon Appelfeld, który ocalał z Zagłady, nigdy nie umiejscowił akcji w getcie, nie wspominając już o obozie. Jego historie zawsze lokują się na obrzeżach i nawet jeśli chodzi o czas, to jego pisarstwo zazwyczaj pozostaje poza ścisłym kręgiem wydarzeń Szoa. Tak jakby dotykał miejsca najświętszego ze świętych. Uderzyło mnie, że bez Grossmana nie jestem w stanie wyobrazić sobie wielkiego szumu wokół drugiego pokolenia. Nawa Semel wydała Kowa zchuchit bodaj rok przed nim, ale jej książka przeszła niemal niezauważona, nie zyskała takiego rozgłosu...

B.K.: Tak też jest z Idą Fink, której twórczością sam się zajmuję. Tłumaczenie jej opowiadań (autorstwa Nachmana Ben-Amiego) ukazało się krótko po wojnie Jom Kippur i nie był to dobry przekład. Potem, kiedy autorka próbowała dotrzeć z opowiadaniami do wydawcy, usłyszała, że w Izraelu tak się nie pisze o Zagładzie. Dopiero w latach 80. zaistniała tam dzięki Dawidowi Weinfeldowi, który zaczął tłumaczyć jej teksty w drugiej połowie dekady.

Sh.R.: A później dostała nagrodę państwową... ${ }^{16}$

B.K.: Tak, ma nawet taką informację na nagrobku, który zresztą jest opisany po hebrajsku, a nie po polsku. Rozmawiałem kiedyś z córką Fink, z którą się przyjaźnię. Mówiła, że jakoś nie przyszło im do głowy, żeby zachować chociaż dwujęzyczność. Ale mówię o tym, bo to bardzo podobna historia. Większość opowiadań Idy Fink powstała w latach 50. Pisarka publikowała je w polskojęzycznej prasie w Izraelu w latach 70. Napotykała mur, mówiono jej, że tak się nie pisze, i nagle w latach 80., na fali mówienia o drugim pokoleniu, jej teksty stały się znane, także dzięki grupie przychylnych krytyków.

Sh.R.: To bardzo ciekawe. Moja koleżanka, która tutaj, na Uniwersytecie Warszawskim, prowadzi translatorium i czyta czasem ze studentami teksty Fink

${ }^{15}$ Zob. A. NAwot: Jelech bi-gdolot gam bi-nefilotaw: al „Ajen erech: ahawa” me'et Dawid Grossman. „Achszaw” 1987, 51-54, s. 553-561.

${ }^{16}$ Ida Fink została uhonorowana Nagrodą Izraela w dziedzinie literatury w 2008 r. 
po polsku i po hebrajsku, mówiła, że Weinfeld w swoim przekładzie zastosował „wyższy” styl. Ona pisała bardzo prosto, a po hebrajsku to brzmi bardziej uroczyście, podniośle.

B.K.: Nie znam tak dobrze hebrajskiego, żeby ocenić dykcję, ale to również problem polskiej recepcji tekstów Fink. Krytycy często skupiają się na tym, że ona pisała „przyciszonym głosem”, dyskretnie, a umykają im tematy, którymi się zajmowała, bardzo oczywiste, takie jak przemoc seksualna, antysemityzm itd. Więc jedną kwestią jest to, jak te książki wpływają na dyskurs - na ile się w niego wpisują, na ile go dekonstruują - a odrębną kwestią jest ich recepcja. Tak jak w przypadku Grossmana - pierwsze recenzje były negatywne, a teraz to fundamentalna książka.

Sh.R.: Były negatywne, to prawda, ale pamiętam, że kiedy Patrz pod: Miłość się ukazała, jej odbiór był niezwykły. Stała się ciosem, ale w dobrym tego słowa znaczeniu. Nie wiem, na ile było to zamierzone, ale bez wątpienia był to ze strony Grossmana gest polityczny. Bo co on w istocie chciał nam powiedzieć? Że każdy $\mathrm{z}$ nas ma $\mathrm{w}$ sobie małego nazistę, pytanie brzmi jedynie, co $\mathrm{z}$ nim zrobi. Czy będzie chciał go przezwyciężyć, czy nie. Przedtem, w Chijuch ha-gdi (1983) pisał o konflikcie izraelsko-palestyńskim. Myślę, że ten problem jest tam obecny, i choć nie jest to książka o Zagładzie, Grossman odwołuje się do niej, żeby podjąć bardziej uniwersalne tematy.

J.B.: Grossman na pewno przetarł pewną ścieżkę, ale wcześniej chyba jeszcze zrobił to Joram Kaniuk powieścią Adam Ben Kelew, chociaż była ona utrzymana $\mathrm{w}$ innej, groteskowej poetyce i nie zyskała aż takiej popularności. Yael Feldman pisała, że to, co zaczął Kaniuk, dokończył Grossman ${ }^{17}$. Ale chyba coś jeszcze się musiało stać. Tak jak mówiłaś, przedstawiciele drugiego pokolenia jako dzieci byli pozbawieni dostępu do narracji zagładowej, a jednak czuli jej obecność i w nieuchronny sposób zaczęli po nią sięgać. Być może Grossman pozwolił lepiej zdać sobie sprawę z tego, że jest potrzeba, by o tym mówić.

Sh.R.: Zgadzam się, myślę, że on czuł ten Zeitgeist, dostrzegł, że nareszcie można to wypowiedzieć. I on w zasadzie stworzył formułę literatury drugiego pokolenia - to jest niesamowite: te wszystkie elementy, które ją definiują, można znaleźć w jego książce, chociaż on sam nie należy do tej generacji.

J.B.: Może on lepiej zdawał sobie sprawę z tego, jakie są cechy tego pokolenia, właśnie dlatego, że w sensie biograficznym nie był jego przedstawicielem.

${ }^{17}$ Y. Feldman: Whose Story Is It, Anyway? In: Probing The Limits of Representation. Nazism and the „Final Solution”. Ed. S. FrIendLÄNDER. Boston 1992, s. 235. 
Sh.R.: Tak, też uważam, że to dzięki oglądowi z zewnątrz, jakim dysponował. Może obserwował swoich przyjaciól, bo to jest mniej więcej ten czas, kiedy drugie pokolenie dojrzało do tego, żeby pisać o swym doświadczeniu. Trochę później zresztą ten temat stał się już w pewien sposób modny, dlatego niezbyt cenię teksty, które wtedy powstały.

J.B.: O tym zresztą Ha-Chamiszija ha-Kamerit zrobił skecz - że każdy z drugiego pokolenia musi coś stworzyć: przedstawiciel tej generacji, pytany w nim o to, co ostatnio namalował, tłumaczy się gęsto, że jest tylko listonoszem... Pisanie o drugim pokoleniu i inna aktywność twórcza stały się w pewnym momencie obowiązkiem. Moi przyjaciele z trzeciego pokolenia, wiedząc, że zajmuję się tym tematem, też czasem żartują, że mogą napisać coś specjalnie dla mnie, żebym miała więcej materiałów do badań. Związek między przynależnością pokoleniową a twórczością doprowadził do jakiejś nadprodukcji... Ale zastanawiałam się nad jeszcze jedną sprawą. Często piszesz o tym, że obrazy Polski czy szerzej cała narracja o Holokauście jest oparta na kliszach. Czy mogłabyś dookreślić, $\mathrm{z}$ czego te klisze są zrobione, co w Izraelu konstruowało te wyobrażenia, skoro Zagłada nie istniała w publicznym dyskursie?

Sh.R.: Ale istniała $\mathrm{w}$ domach, więc $\mathrm{z}$ jednej strony ten przekaz kształtował postrzeganie Polski. Myślę, że wpływ na to miała też literatura, na przykład powieść Jerzego Kosińskiego Malowany ptak, która była tłumaczona na hebrajski. Przedstawiony w niej obraz, jak się często zakłada - polskiej, wsi jest dość ponurą wizją kraju i jego mieszkańców. Z drugiej strony - w moim przypadku było inaczej. Choć należę do drugiego pokolenia, moja matka nie pochodzi z Polski i jedyne, co pamięta, to swój pobyt na Węgrzech, w związku z czym nie przekazała mi żadnego konkretnego obrazu Polski.

Jakie są stereotypy Polski? Że to jest szare miejsce, ogromny cmentarz, że Polacy są strasznymi antysemitami. A skąd takie wyobrażenie? Sama się zastanawiam. Tego na pewno nie uczyłam się w szkole. Nie było przecież żadnych spotkań ani innych form kontaktu, Polska była zamknięta, stanowiła część bloku wschodniego. Polacy jako część Układu Warszawskiego - 1956, 1968. Jak to jest, że w 1968 roku właściwie bez Żydów istniał tak silny antysemityzm? Kiedyś na poświęconej pamięci konferencji w Izraelu, organizowanej przez psychiatrów i psychologów, jedna $z$ organizatorek mówiła, że te konferencje zaczynały się we współpracy polsko-niemiecko-izraelskiej, ale taka forma się nie sprawdziła, bo Polacy czuli się marginalizowani, dlatego trzeba było ograniczyć współpracę do relacji polsko-izraelskich, już bez Niemców.

J.B.: Dialog między Izraelem a Niemcami zaczął się wcześniej, ale nie ma w nim rywalizacji o status ofiary, jaka towarzyszy kontaktom polsko-izraelskim. 
Sh.R.: Mnie zawsze zastanawia to, że Polacy tak bardzo chcą być postrzegani jako nieskalane ofiary. To jest świetny temat na satyrę, ale takiej chyba w polskiej telewizji nie ma, a już zwłaszcza teraz nie może być. Pamiętam natomiast, że w Izraelu tego typu programy były emitowane w telewizji i to na głównych kanałach.

J.B.: W ogóle myślę, że telewizja - przez to, jak działa - daje pod tym względem ogromne możliwości, o ile oczywiście nie funkcjonuje pod dyktando aktualnej władzy. To też pokazuje, jak trudna sytuacja polityczna sprzyja satyrze. Co zresztą teraz widać doskonale w Izraelu.

B.K.: Wydaje mi się, że to medium trochę przebrzmiałe, wszyscy się przenoszą do Sieci.

Sh.R.: Może jeszcze też teatr, chociaż jego poziom w Izraelu jest bardzo niski. Zastanawiałam się niedawno, dlaczego teatr nadal reprezentuje tak niski poziom, podczas gdy kino jest takie dobre i potrafi znaleźć znakomite scenariusze. Są wprawdzie Hanoch Levin i Nissim Aloni, ale naprawdę teatr izraelski nie jest najciekawszy. Jest sztuczny, nieprzekonujący, może poza teatrem bardziej eksperymentalnym.

J.B.: Wielu młodych twórców wyjechało z Izraela, bo trudno było im pogodzić się z konsekwencjami tamtejszej polityki, choć oczywiście są także inne powody. Część z nich żyje i pracuje na przykład w Berlinie, jak Yael Ronen, córka reżysera Ilana Ronena, który pracował w Hajfie. Mam też koleżankę, która poszła do wojska na Terytoria Okupowane, bo tyle o nich słyszała i chciała na własne oczy przekonać się, co tam się dzieje, a potem, zaraz po zakończeniu służby, wyjechała z Izraela.

Sh.R.: Ale to jest prawda, że Izraelczycy nie wiedzą i nie chcą wiedzieć. Konfrontacja z palestyńską wersją historii nie jest częścią zbiorowego doświadczenia.

J.B.: Dość dobrze opisuje to Noam Chajot w powieści Ganewet ha-Szo'a szeli... ${ }^{18}$. W jednej ze scen główny bohater, służący w armii izraelski Żyd, podczas akcji w Strefie Gazy napotyka wzrok przerażonej palestyńskiej dziewczynki, która kojarzy mu się z chłopcem ze słynnego zdjęcia zrobionego $\mathrm{w}$ warszawskim getcie. Nagle pojmuje, że Żydzi nie są jedynymi ofiarami i że tuż obok żyje naród obciążony własną traumą.

Sh.R.: Można by to w pewnym stopniu porównać do tego, jak w Polsce funkcjonuje narracja o grabieży majątków żydowskich i wypędzeniach Niemców.

\footnotetext{
${ }^{18}$ N. Снајот: Ganewet ha-Szo’a szeli: reszimot szek cair israeli. Tel Awiw 2009.
} 
Nie jest zresztą tak, że w Izraelu nie można mówić na ten temat. Wspomina się czasem o domach niegdyś należących do Palestyńczyków, ale nie jest to kwestia chętnie poruszana.

J.B.: Wydaje mi się, że Zagłada służy do opowiadania o tym doświadczeniu, bo jest na tyle zadomowiona w dyskursie, że użycza języka innym tematom.

Sh.R.: Jest pewnego rodzaju paradygmatem, ale trzeba też pamiętać, że temat Nakby także nie jest dla izraelskich twórców nowy - to raczej kwestie, które wcześniej były niewidoczne, teraz ze względu na rząd doszły do głosu. Na przykład w latach 60. Awraham Ben Jehoszua pisał w swoim opowiadaniu Naprzeciw lasów o wiosce, z której wypędzono arabskich mieszkańców. Arabowie są tam pokazywani jako pozbawieni języka. W latach 80 . na problem zwracał uwagę Jeszajahu Lejbowic, bardzo ważna postać w Izraelu, filozof, który mówił o żydowskich nazistach. Mniej więcej do pierwszej intifady można było próbować udawać, że da się o tym zapomnieć, ale teraz już wszyscy o tym mówią.

J.B.: Boaz Gaon w dramacie Ha-Sziwa le-Hejfa (2008) opisuje powrót rodziny palestyńskiej do domu, z którego została wypędzona w 1948 roku. Okazuje się, że w międzyczasie zamieszkała w nim już rodzina ocalałych z Zagłady. To dość wyraziste zestawienie...

Sh.R.: Poeta Awot Jeszurun już w latach 50. widział w palestyńskich uchodźcach Żydów przybyłych po Zagładzie z Polski, mówił o dwóch Holokaustach. Te porównania oczywiście nie przebijały się do mainstreamu, dopiero w latach 70. i 80. Jeszurun zyskał popularność, był drukowany, pisał też więcej. Jego pokolenie - między innymi Awram Szlonski i Natan Alterman - niezbyt go akceptowało, ale już następne traktowało go jak jednego ze swoich. Wcześniej nie zyskał takiego uznania, bo wyprzedzał swoje czasy. Tak że to chyba nie kwestia nowości, ale rozłożenia akcentów - te głosy się pojawiały, ale nie były ciekawe dla społeczeństwa, pozostawały niezauważone. Więc współczesne zestawianie Zagłady i losu Palestyńczyków nie jest zupełną nowością, po prostu teraz stało się nieuniknione.

J.B.: Poza tą linią: Nakba - Holokaust, jest jeszcze sprawa, która mocno tu rezonuje, mianowicie Mizrachim ${ }^{19}$. Ostatnio sporo dyskutowano w Izraelu o filmie Sallach, po ze Erec Israel (2017, reż. Dawid Deri), który opowiada o szczegółach operacji przeniesienia do Izraela Żydów z Afryki Północnej i Bliskiego Wschodu

${ }^{19}$ Mizrachim (od: mizrach 'wschód') to trwale zakorzenione w izraelskim społeczeństwie, generalizujące określenie żydowskich obywateli przybyłych do Izraela z terenów Bliskiego Wschodu i Afryki Północnej. 
oraz o krzywdach, jakich doznali oni ze strony urzędników państwowych. Zastanawiam się, na ile to celowe, ale sposób przedstawienia tej kwestii właściwie uniemożliwiał oddzielenie tego tematu od problemu Zagłady.

Sh.R.: To ma związek z polityką tożsamości - teraz Mizrachim, a właściwie ich samozwańczy przedstawiciele, starają się pokazywać własną Zagładę, udowadniać, że Żydzi w Tunezji czy Grecji też byli poszkodowani. To jest nowe pole rywalizacji o status największej ofiary, co zawsze wywołuje we mnie obrzydzenie - czy to w odniesieniu do Polski i Izraela, czy w tym przypadku. W tej narracji to Aszkenazyjczycy stają się nowymi nazistami, a Mizrachim są najbardziej poszkodowani. Podkreślają oni wszystkie stereotypowe cechy, jakie się im przypisuje - nie rozumiem, w jakim celu to robią. Mam studentkę, która pisze pracę o Ars Poetica, grupie radykalnych poetów Mizrachim poruszających kwestie polityczne, ale ja jestem już za stara, żeby się wzruszać przy poezji, czasem mi się to zdarza, kiedy czytam Tadeusza Różewicza - to musi być poeta takiego formatu.

J.B.: To dlatego zdecydowałaś się pisać w swojej książce tylko o prozie?

Sh.R.: Teraz zajmuję się poezją, piszę właśnie o Awocie Jeszurunie i okazuje się, że w jego utworach też jest dużo materiału na temat Zagłady i Polski.

B.K.: Ale jesteśmy także $\mathrm{w}$ jakimś punkcie przełomowym - dostrzegam od kilku lat pewien regres w pamięci Zagłady. Sam pracuję między innymi jako nauczyciel i widzę to po moich uczniach. W zasadzie są pozbawieni wiedzy, przez co można ich dowolnie kształtować i bliskie są im często obrazy żołnierzy wyklętych.

J.B.: To jest również ciekawe w Izraelu. Nieustannie mówi się o Zagładzie, nawet w przedszkolu jest - słyszałam, że tak się tłumaczy dzieciom - Jom ha-Szual we ha-Dwora (Dzień Liska i Pszczółki - zamiast Jom ha-Szoa we ha-gwura, czyli Dzień Zagłady i Bohaterstwa), pewnie bardziej po to, żeby dzieci nie bały się syren i nie myślały, że to alarm. Ale nie oznacza to, że wszyscy są świetnie wyedukowani - raczej kojarzą, że była Zagłada i trzeba się bronić, żeby nie było drugiej...

Sh.R.: To jest bardzo ciekawa kwestia, nie mam pojęcia, trzeba by pewnie zapytać nauczycieli. Mogę tylko powiedzieć, że ja sama byłam w dobrej szkole, ale na historii zajmowaliśmy się głównie pogromami, nie przywiązywano większej wagi na przykład do różnic pomiędzy poszczególnymi wizjami syjonistycznymi. Moja klasa miała co prawda lepszego nauczyciela, który uczył więcej historii powszechnej, ale w innych klasach naprawdę w końcu wszyscy mieli już dość. 
Kiedy na lekcjach omawiano współczesność, to znaczy czasy po powstaniu Państwa Izrael, mówiono przede wszystkim o poszczególnych miwca’im, operacjach wojskowych. Jedna klasa nie mogła tego słuchać do tego stopnia, że uczniowie oddali prace pisemne o operacji, której nigdy nie było - wymyślili przebieg, dowódców itd. I dostali bardzo dobre oceny...

B.K.: Z tego wzięły się też różnego rodzaju fake testimonies - Benjamin Wilkomirski, Misha Defonseca itd ${ }^{20}$. Przypominam sobie rozmowę z książki Agnieszki Daukszy Klub Auschwitz... ${ }^{21}$, w której jeden z Polaków ocalałych z obozu mówił, że zazdrości Żydom terminu „Holokaust”, bo jest mocny i dobitnie nazywa zjawisko, a on nie ma się do czego odwołać.

J.B.: Koncept wymyślania historii wydaje się dużym problemem. Pewne rzeczy są tak zakorzenione w naszej świadomości, że mogą służyć jako matryca procesów myślowych. Twoi koledzy mogli „wyprodukować” nieistniejącą operację wojskową, bo słyszeli o tylu innych, że doskonale wiedzieli, jak to zrobić. Wszystkie kawałeczki mieli gotowe w głowach, tylko trzeba je było inaczej złożyć.

Sh.R.: Tak, to działa na zasadzie gotowej formuły, wystarczy jedynie dopełnić ją szczegółami.

B.K.: My pewnie moglibyśmy sobie wymyślić jakieś powstanie. To jest zresztą straszne, że mimo prób odejścia od martyrologii, skupienia się na życiu codziennym, na uczeniu w inny sposób, okazuje się, że chociażby książki powstające w Centrum Badań nad Zagładą Żydów zupełnie nie docierają do szerszego grona odbiorców, można wygłaszać publicystyczne tezy zupełnie obok nich, jakby nie istniały.

Sh.R.: Zastanawiam się, jaka jest różnica między sytuacjami w obydwu krajach. Myślę, że obecnie w Polsce panuje taka atmosfera, jakby w ogóle nie trzeba było zajmować się niczym praktycznym, codziennym - że cała energia może się skupiać na przeszłości. A w Izraelu to nie jest możliwe z przyczyn politycznych. Nawet jeśli politycy chcieliby zająć się czymś innym, muszą myśleć o teraźniejszości. Chociaż przez ostatnich kilka lat było trochę spokojniej, więc może znów

20 Zob. B. Wilkomirsкi: Bruchstucke. Aus einer Kindheit 1939-1948. Frankfurt am Main 1996; M. Defonseca: Survivre avec les Loupis. Paris 1997. W USA publikacja ukazała się jako: Misha: A Mémoire of the Holocaust Years. Gloucester, Massachusetts 1997; polskie wydanie: Przeżyć $z$ wilkami. Przeł. J. Kluza. Katowice 2008.

${ }^{21}$ Zob. A. Dauksza: Klub Auschwitz i inne kluby. Rwane opowieści przeżywców. Gdańsk 2016, s. 17. Mowa o wypowiedzi Stefana Lipniaka: „Zazdroszczę Żydom Holokaustu” - rozmówca szybko dopowiedział jednak, że ma na myśli sam termin, dzięki któremu „od razu wiadomo, o co chodzi". 
uda im się wrócić do przeszłości i tworzenia jakiejś nowej mitologii. Ciekawe jest też, że - podobnie jak w Polsce - w Izraelu właściwie nie ma już lewicy. Merec to bardzo mała partia, dawna Partia Pracy to właściwie już prawica. Między Netanjahu a Lapidem toczy się spór o to, kto lepiej obroni Izrael...

J.B.: Zresztą skandal związany z ustawą, o której mówiliśmy, pojawił się w bardzo wygodnym dla rządu momencie, bo przynajmniej na chwilę odwrócił uwagę od dyskutowanej szeroko w Izraelu kwestii uchodźców z Erytrei i Sudanu...

Sh.R.: I tu też trudno uciec od porównań do Zagłady...

J.B.: Tak, jedna $\mathrm{z}$ organizacji zrzeszających ocalałych zadeklarowała nawet, że będzie ukrywać ich w swoich domach...

Sh.R.: Oczywiście nie chodzi o zestawianie cierpienia jednych i drugich albo o porównywanie ich doświadczeń. Te podobieństwa mają wymiar symboliczny, odwoływanie się do nich wynika $\mathrm{z}$ tego, że dysponujemy takim, a nie innym językiem, ukształtowanym przez Szoa. Skojarzenia tego typu są nieuniknione, bo najbardziej znaczące. Trudno znaleźć coś lepszego. 